SANDRA CICHORZ

MALGORZATA MALICKA

MARIA GOŚKA

Instytut Hodowli i Aklimatyzacji Roślin — Państwowy Instytut Badawczy, Radzików

Kierownik Tematu: dr Sandra Cichorz Instytut Hodowli i Aklimatyzacji Roślin - Państwowy Instytut

Badawczy, Radzików, 05-870 Błonie, Oddział, Bydgoszcz, Al. Powstańców Wielkopolskich 10,

85-090 Bydgoszcz, tel. 52 5816918, e-mail: s.cichorz@ihar.bydgoszcz.pl

Prace zostały wykonane $w$ ramach badań podstawowych na rzecz postęu biologicznego $w$ produkcji roślinnej na podstawie decyzji Ministra Rolnictwa i Rozwoju Wsi nr HOR.hn.802.19.2018, Zadanie 46.

\title{
Badania nad mechanizmami warunkującymi proces embriogenezy gametycznej u buraka cukrowego
}

\author{
The research on the mechanisms responsible for gametic embryogenesis \\ in sugar beet
}

Słowa kluczowe: AGP, Beta vulgaris, gynogeneza, haploidy

W ostatnich kilkunastu latach nieodzownym elementem strategii tworzenia nowych materiałów wyjściowych dla hodowli, jak również doskonalenia odmian buraka cukrowego stało się wykorzystanie najnowszych osiągnięć w dziedzinie biotechnologii. Otrzymanie haploidów tego gatunku okazało się możliwe dopiero w latach 80 . z wykorzystaniem kultur in vitro niezapłodnionych zalążków i zalążni (Van Geyt i in., 1987; Doctrinal i in., 1989; Gośka, 1997), podczas których dochodzi do regeneracji haploidalnych pędów z komórek jajowych woreczka zalążkowego. Rośliny haploidalne są niepłodne, $\mathrm{z}$ tego względu niezbędna jest ich diploidyzacja dla uzyskania stabilnych genetycznie i cytologicznie linii podwojonych haploidów (linii DH). Jednak wykorzystanie linii DH w hodowli roślin w znacznym stopniu uwarunkowane jest efektywną metodą ich wyprowadzenia $\mathrm{z}$ różnych materiałów wyjściowych. Wpływ genotypu uważany jest za najważniejszy czynnik warunkujący efektywność prawie wszystkich rodzajów kultur tkankowych, a w szczególności embriogenezy gametycznej. Obecnie niewiele wiadomo na temat mechanizmów molekularnych, w tym udziału poszczególnych genów związanych z indukcją powyższego procesu. Przy czym warto podkreślić, iż identyfikacja genotypów o wysokim potencjale gynogenetycznym byłaby 
wysoce pożądana. Dlatego też, aby poszerzyć wiedzę na temat genetycznych mechanizmów warunkujących rozwój haploidalnych zarodków nieodzowne są badania prowadzone na szeroką skalę, szczególnie genotypów o wysokim i niskim potencjale gynogenetycznym buraka cukrowego (Bohanec, 2009).

Z powyższych względów punktem wyjścia prowadzonych prac była między innymi cytologiczna charakterystyka komórek zalążka buraka. Zaobserwowano, iż podczas prowadzenia kultur zapłodnionych zalążków buraka cukrowego, dochodzi do zmian w obrębie ścian komórek integumentum (Bruun, 1991). Zgodnie $\mathrm{z}$ danymi literaturowymi, obecność poszczególnych komponentów ściany, jak też ich przestrzenna organizacja są potencjalnymi czynnikami odzwierciedlającymi lub w pewnym stopniu warunkującymi właściwości morfogenetyczne komórek i tkanek. Badania prowadzone na 3 liniach kalusa buraka cukrowego (normalnego, nieorganogenicznego i rakowego) różniących się potencjałem morfogenetycznym wykazały, iż w toku prowadzenia kultur dochodzi do zróżnicowanej ekspresji peroksydaz, chitynaz, esteraz pektynowych. Powyższe enzymy uczestniczą $\mathrm{w}$ modyfikowaniu właściwości komponentów ściany komórkowej, przy czym chitynazy biorą udział w szlaku przemian części białkowej arabinogalaktanów, zawierających N-acetylo-D-glukozamię (GlcNAc) oraz glukozaminę $(\mathrm{GlcN})$, co prowadzi do uwolnienia oligosacharydowych cząsteczek sygnalnych (Pavoković i in., 2012). Obecny stan wiedzy pozwala stwierdzić istotną rolę komponentów ściany komórkowej jakimi są proteoglikany AGP (ang. arabinogalactan proteins) w procesach wzrostu łagiewki pyłkowej, wydłużania i różnicowania komórek, a także regulacji somatycznej embriogenezy (Capataz-Tafur i in., 2011). Ponadto wykazano obecność AGP w organach wegetatywnych i generatywnych roślin, w tym również w zalążkach (Acosta-Garcia i Vielle-Calzada, 2004; Qin i Zhao, 2006). Wyniki przytoczonych prac eksperymentalnych sugerują, że proteoglikany AGP pełnią istotną rolę w procesach morfogenezy roślin.

Dlatego też uznano za celowe porównanie struktury ścian komórkowych syntetyzowanych przez trudno i łatwo regenerujące na drodze gynogenezy genotypy buraka cukrowego, ze szczególnym uwzględnieniem lokalizacji i rearanżacji wybranych proteoglikanów i pektyn.

Obserwacje histologiczne w mikroskopie świetlnym prowadzone na skrawkach cienkich $(1 \mu \mathrm{m})$ wykazały, że izolacja niezapłodnionych zalążków z roślin donorowych odbyła się między 1-3 dniem przed stadium antezy, zaś woreczek zalążkowy był w pełni rozwinięty, dojrzały i prawidłowo zorganizowany. W przypadku genotypów o wyższym potencjale embriogenetycznym po 7 dniach od wyłożenia na pożywki regeneracyjne w niezapłodnionych zalążkach woreczek zalążkowy powiększył się, zaś synergidy uległy resorpcji. Na kolejnym etapie (po 9 dniach) widoczne były pierwsze podziały komórki jajowej i tworzenie się dwukomórkowego prazarodka. Natomiast po 14 dniach zaobserwowano rozwój trzykomórkowego prazarodka. W przypadku genotypów o niższym potencjale embriogenetycznym zaobserwowano degradację komórek w woreczku zalążkowym, a także nieprawidłowy rozwój tumorowatych struktur w jego wnętrzu, czyli wtórną embriogenezę. 
Obecność i dystrybucja epitopów charakterystycznych dla jednego typu proteoglikanów AGP i pektyn została wstępnie zbadana w tkankach niezapłodnionych zalążków buraka cukrowego o wysokim i niskim potencjale embriogenetycznym, utrwalonych na czterech etapach rozwojowych (w dniu pobrania oraz po 7, 9 i 14 dniach od wyłożenia na pożywki indukcyjne). Detekcję przeprowadzono na skrawkach półcienkich $(0,5 \mu \mathrm{m})$. Miejsce wiązania przeciwciał przez antygeny komórkowe uwidoczniono in situ po przyłączeniu przeciwciał wtórnych znakowanych izotiocyjanianem fluoresceiny (FITC) zgodnie z metodyką opisaną przez Wiśniewską i Majewską (2007). Preparaty analizowano w mikroskopie fluorescencyjnym Jenalumar. Obserwacje mikroskopowe ujawniły występowanie w znacznych ilościach relatywnej zawartości domen strukturalnych charakterystycznych dla pektyn rozpoznawanych przez przeciwciało LM6. Natomiast obecności domen strukturalnych rozpoznawanych przez przeciwciało JIM14 odnotowano w śladowych ilościach. Analiza detekcji powyższych komponentów ściany komórkowej wykazała, że ich rozmieszczenie przebiegało według schematu porównywalnego dla wszystkich genotypów. Reakcje kontrolne do powyższych analiz, wykonane $\mathrm{z}$ pominięciem etapu inkubacji z przeciwciałem pierwotnym, wykazały brak znakowania komórek zalążka, co świadczy o poprawnym wykonaniu analiz immunocytochemicznych.

Epitopy charakterystyczne dla pektyn zlokalizowano przy pomocy przeciwciała LM6. W zalążkach przed wyłożeniem na pożywki regeneracyjne wyraźne znakowanie obserwowano głównie w ścianie komórkowej woreczka zalążkowego oraz nieco słabsze w ścianach komórek nucellusa sąsiadujących z biegunem mikropylarnym. W pozostałych komórkach nucellusa, osłonek i podstawy zalążka odnotowano słabsze, lecz równomierne znakowanie. W miarę inicjacji i rozwoju prazarodka $(7,9,14$ dzień kultury) obecność epitpów polisacharydowych wokół woreczka zalążkowego zanikała, utrzymując nieco wyższy poziom znakowania w części mikropylarnej nucellusa. Ponadto, widoczne sygnały wskazujące na obecność AGP zawierających epitopy reagujące z LM6 odnotowano w formujących się ścianach dwu- i trzykomórkowego prazarodka.

W przypadku lokalizacji epitopów charakterystycznych dla polisacharydowej części proteoglikanów AGP rozpoznawanych przez przeciwciało JIM14 w zalążkach przed wyłożeniem na pożywki regeneracyjne wyraźne znakowanie obserwowano w ścianie komórkowej woreczka zalążkowego oraz ścianach komórek nucellusa sąsiadujących z biegunem mikropylarnym. W pozostałych komórkach nie stwierdzono znakowania powyższych epitopów. W kolejnych dniach prowadzenia inicjacji regeneracji obecność epitopów polisacharydowych wokół woreczka zalążkowego zanikała, utrzymując niski poziom znakowania w komórkach kolumnowych kanału mikropylarnego.

Z powyższych względów uznano, iż obecność i lokalizacja określonych domen cukrowych może mieć istotny wpływ na proces embriogenezy gametycznej buraka cukrowego, co wymaga potwierdzenia większą liczbą obserwacji w toku kolejnych badań. 


\section{LITERATURA}

Acosta-García G., Vielle-Calzada J. P. 2004. A Classical Arabinogalactan Protein Is Essential for the Initiation of Female Gametogenesis in Arabidopsis. Plant Cell 16: 2614 - 2628.

Bohanec, B. 2009. Doubled haploids via gynogenesis. In: Advances in Haploid Production in Higher Plants (Touraev A., Forster B. P., Jain S. M. eds). Heidelberg, Berlin: Springer-Verlag: 35 - 46.

Bruun L. 1991. Histological and semi-quantitative approaches to in vitro cellular responses of ovule, embryo and endosperm in sugar beet, Beta vulgaris L. Sex Plant Reprod 4: 64 - 72.

Doctrinal M., Sangwan R.S., Sangwan-Norreel B.S. 1989. In vitro gynogenesis in Beta vulgaris L.: Effects of plant growth regulators, temperature, genotypes and season. Plant Cell Improvement 12: $346-357$.

Capataz-Tafur J., Trejo-Tapia G., Rodr1'guez-Monroy M., Sepu'lveda-Jime'nez G. 2011. Arabinogalactan proteins are involved in cell aggregation of cell suspension cultures of Beta vulgaris L. Plant Cell Tiss. Org. 106: $169-177$.

Gośka M. 1997. Haploidy i podwojone haploidy buraka cukrowego (Beta vulgaris L.) oraz możliwości ich wykorzystania w hodowli. Monografie i Rozprawy Naukowe IHAR 2: $1-81$.

Pavoković D., Poljuha D., Horvatic' A., Ljubes ic' N., Hage'ge D., Krsnik-Rasol M. 2012. Morphological and proteomic analyses of sugar beet cultures and identifying putative markers for cell differentiation. Plant Cell Tiss. Org. 108: $111-119$.

Qin Y., Zhao J. 2006. Localization of arabinogalactan proteins in egg cells, zygotes, and two-celled proembryos and effects of $\beta$-D-glucosyl Yariv reagent on egg cell fertilization and zygote division in Nicotiana tabacum L. Exp. Bot. 57: 2061 - 2074.

Wiśniewska E., Majewska-Sawka A. 2007. Arabinogalactan-proteins stimulate the organogenesis of guard cell protoplasts-derived callus in sugar beet. Plant Cell Rep. 26: 1457 - 1467.

Van Geyt J. P. C., Speckmann G. J., D 'Halluin K., Jacobs M. 1987. In vitro induction of haploid plants from unpollinated ovules and ovaries of the sugarbeet (Beta vulgaris L.) Theor. Appl. Genet. 73: 920 — 925. 